Meta

Journal des traducteurs

Translators' Journal

\title{
On Using On-Line Data-Based for Help in Technical Translating
}

\section{Gerald Brace}

Volume 26, numéro 1, mars 1981

L'informatique au service de la traduction

Machine Aids to Translation

URI : https://id.erudit.org/iderudit/002138ar

DOI : https://doi.org/10.7202/002138ar

Aller au sommaire du numéro

Éditeur(s)

Les Presses de l'Université de Montréal

ISSN

0026-0452 (imprimé)

1492-1421 (numérique)

Découvrir la revue

Citer cet article

Brace, G. (1981). On Using On-Line Data-Based for Help in Technical

Translating. Meta, 26(1), 81-84. https://doi.org/10.7202/002138ar d'utilisation que vous pouvez consulter en ligne.

https://apropos.erudit.org/fr/usagers/politique-dutilisation/ 


\section{On Using On-Line Data-Bases for Help in Technical Translating}

Gerald Brace

There are times when on-line data-bases can be of help in translating specific technical words that cannot be readily found in dictionaries or the literature. I would like to give two such examples because I feel that they cast some light on the possibilities becoming available in this field.

\section{Torseur}

I came across the word torseur in a text on the designing of tankers. Linguistically mathematics is treated with respect in France, and a good many abstruse terms have found their way into the public domain. There is even a perfectly good definition of torseur in the Petit Larousse1, but none of the bilingual or multilingual dictionaries I consulted ${ }^{2}$ gave a satisfactory translation. The only one to give a translation at all was Harrap's ${ }^{3}$, but it gives torque as the English equivalent, which is obviously erroneous.

My next reaction was to consult the experts here at the Institut français du pétrole (IFP). Many of them knew the word, and several even began explaining its precise meaning in detail. But none of them knew what the English term was.

Therefore, I decided to consult the CNRS data-base $P A S C A L^{4}$ which is indexed in both French and English. Titles in English are not translated into French but are indexed with both French and English descriptors in the fields of information science, energy, earth sciences and metallurgy. A query for documents in English containing the descriptor torseur produced 22 of them, and when the titles were printed out the English word turned out to be twistor. I found this word in two sources ${ }^{5}$, although with a different meaning because it

1. PETIT LAROUSSE ILLUSTRÉ, Librairie Larousse, Paris, 1980.

2. DICTIONARY OF PETROLEUM TECHNOLOGY, M. Moureau and G. Brace, Éditions Technip, Paris, 1979; HARRAP'S NEW STANDARD FRENCH AND ENGLISH DICTIONARY, J. E. Mansion, ed. by R. P. L. Ledésert and M. Ledésert, George G. Harrap \& Co. Ltd., London, 1972; FRENCH AND ENGLISH DICTIONARY OF MATHEMATICAL VOCABULARY, W. D. Lyle, Montreal, 1970; MATHEMATICS DICTIONARY, third edition, James \& James, D. Van Nostrand Co., Inc., Princeton, 1968; THE INTERNATIONAL DICTIONARY OF APPLIED MATHEMATICS, D. Van Nostrand Co., Inc., Princeton, 1960.

3. HARRAP'S NEW STANDARD FRENCH AND ENGLISH DICTIONARY, 1972, op. cit.

4. PASCAL (Bulletin Signalétique du Centre National de Recherche Scientifique), Centre de Documentation Scientifique et Technique du CNRS, online supplier Questel-Télésystèmes, Paris, and ESA-IRS, Frascati, Italy.

5. MCGRAW-HILL DICTIONARY OF SCIENTIFIC AND TECHNICAL TERMS, second edition, D. N. Lapedes Ed. in Chief, McGraw-Hill Book Co., New York, 1978; STANDARD DICTIONARY OF COMPUTERS AND INFORMATION PROCESSING, M. H. Weik, Hayden Book Co., Inc., New York, 1970. 
was described as being a type of computer memory element. However, the excellent pertinence of the 22 references given by PASCAL and their sheer number were sufficient to convince me that twistor is a valid translation for torseur $^{6}$.

It is interesting to note that, from the time I decided to consult the database, it took only a couple of minutes to find the answer I was looking for. This can be compared with the hour or two I spent telephoning the IFP specialists in mathematics and physical mechanics and discussing the problem with them.

\section{Argilocinèse}

The second example is perhaps an even more interesting one. It has to do with the word argilocinèse which was presented all by itself as a heading on a panel to be displayed at a geological conference. Therefore, there was no context and no way to work around finding a direct expression for the same concept in English. The draftsman was waiting for my translation to complete the panel, and all the IFP geologists were at a meeting preparing for the conference. So I had to find a solution.

I of course consulted all the standard dictionaries and sources in the field ${ }^{7}$, and there was nothing at all. The word argilocinèse itself is entirely transparent, coming from the twin Greek roots argill or argilli or argillo (containing clay) and-kinesis (movement) ${ }^{8}$. There is the perfectly correct English-language word argillaceous based on the first of these roots.

So then I turned to the computer and queried the leading geological databases, Tulsa (Petroleum Abstracts) ${ }^{9}$ and GeoRef ${ }^{10}$. We truncated the word and tried with argillo- argilli-, argilo- and argili-. No success whatsoever. The word apparently does not exist in English.

The next thing we tried was to question $P A S C A L^{11}$ in hopes that a document in English had been indexed in French with argilocinèse. Right away we got an excellent bite in an article published in 1977 with the title "Argilocinèse : type de déformation synsédimentaire des bassins de dépôt". And we were told that there was an abstract in English.

6. "TWISTORS AND MULTIPOLE MOMENTS," G. E. Curtis, Proceedings of the Royal Society of London, Vol. 359, No. 1697, p. 133-149, 15 February 1978.

7. DICTIONARY OF PETROLEUM TECHNOLOGY, 1979, op. cit.; GEOLOGICAL NOMENCLATURE, A. A. G. Schieferdecker, J. Noorduijn en Zoon N.V., Gorinchem, the Netherlands, 1959; VOCABULAIRE-FRANCO-ANGLO-ALLEMAND DE GEOMORPHOLOGIE, H. Baulig, Les Belles Lettres, Paris 1956; GLOSSARY OF GEOLOGY, ed. by R. L. Bates and Julia A. Jackson, American Geological Institute, Falls Church, Virginia, 1980.

8. WEBSTER'S NEW COLLEGIATE DICTIONARY, G. \& C. Merriam Co., Springfield, Massachusetts, 1977; WEBSTER'S THIRD NEW INTERNATIONAL DICTIONARY, G. \& C. Merriam Co., Springfield, Massachusetts, 1966.

9. TULSA (Petroleum Abstracts), The University of Tulsa, online supplier ORBIT-SDC, Santa Monica.

10. GEOREF (Geological Reference File), American Geological Institute, online supplier ORBITSDC, Santa Monica.

11. PASCAL (Bulletin Signalétique du Centre National de Recherche Scientifique), op. cit. 
Once we had succeeded in locating the publication containing the article, we found that the first sentence was a wonderfully clear definition of argilocinèse. It reads as follows :

L'Argilocinèse est une tectonique synsédimentaire où jouent uniquement des forces de gravité et dans laquelle la couverture sédimentaire est déformée par des mouvements d'argiles sous-compactées (les argiles mobiles).

The English translation of the title and of this first sentence was :

\section{ARGILOCINESIS - A TYPE OF SYNSEDIMENTARY DEFORMA- TION OF SEDIMENTARY BASINS}

Argilocinesis is a synsedimentary tectonic, where only forces of gravity come into play and in which the sedimentary cover is distorted by movements of low density clay (mobile clay).

Since I had already searched to see whether argilokinesis existed ${ }^{12}$ and had not found it, then there was no reason to accept argilocinesis as the translation I was looking for. Therefore, without commenting any further on the accuracy or quality of this translation, as far as solving my own problem went, I was right back at square one.

However, there is a word I know which has a similar construction: halokinesis, which quite simply means salt tectonics ${ }^{13}$. Therefore, my first instinct was to create the term clay tectonics. But a check in the Tulsa and GeoRef data-bases did not reveal any cases where this term was used. So other tactics had to be devised.

In the literature, clay is used more specifically to refer to the mineral, whereas shale is used to refer to rock formations containing a high percentage of clay. Therefore, a search was made with the term shale tectonics, although to no avail.

In looking up the term salt tectonics ${ }^{14}$ to try to widen the search, I found that references were made to salt domes and diapirs. And since the terms diapirism and diastrophism are often used when referring to tectonics, various combinations were tried with these terms. The one that turned out to be the right one was finally shale diapirism since the GeoRef data-base gives 38 references, including a $\mathrm{PhD}$ thesis ${ }^{15}$. Therefore, we can conclude that argilocinèse can be rendered in English by shale diapirism, even though the French term is somewhat more generic than the English one, but this phenomenon is not unusual in that English often tends to use more specific terminology than French.

12. WEBSTER'S NEW COLLEGIATE DICTIONARY, 1977, op. cit.; WEBSIER'S IHIKU NEW INTERNATIONAL DICTIONARY, 1966, op. cit.: GLOSSARY OF GEOLOGY, 1980 , op. cit.

13. DICTIONARY OF PETROLEUM TECHNOLOGY, 1979, op. cit.; GLOSSARY OF GEOLOGY, 1980, op cit.

14. GLOSSARY OF GEOLOGY, 1980, op. cit.

15. SHALE DIAPIRISM AND COMPACTION OF ABNORMALLY PRESSURED SHALES IN SOUTH TEXAS, R. S. Bishop, Standford University, 1977. 


\section{Conclusion}

Two examples have been given of how on-line data-bases can be used to search for the translation of specific terms. The first example gave a direct result in a very short space of time. The second example, however, was more complex and, in addition to knowing something about the subject, required a thought process going by way of a different word having the same type of construction. This second search, of course, took somewhat more time, but it is an excellent example of how computerized documentation can be used as a help in translating by providing pinpoint access to a vast body of literature. 